\title{
The Immunomodulatory Function of Vitamin D, with Particular Reference to SARS-CoV-2
}

\author{
Alberto Caballero-García ${ }^{1}$, David C. Noriega ${ }^{2}$, Hugo J. Bello ${ }^{3}$, Enrique Roche ${ }^{4,5}$ (i) \\ and Alfredo Córdova-Martínez ${ }^{6, *}$ (i)
}

1 Department of Anatomy and Radiology, Health Sciences Faculty, GIR of Physical Exercise and Aging, Campus Universitario "Los Pajaritos", 42004 Soria, Spain; alberto.caballero@uva.es

2 Spine Department, Valladolid University Hospital, University of Valladolid, 47005 Valladolid, Spain; noriega1970@icloud.com

3 Department of Mathematics, School of Forestry Industry and Agronomic Engineering and Bioenergy, GIR of Physical Exercise and Aging, Campus Universitario "Los Pajaritos", 42004 Soria, Spain; hjbello.wk@gmail.com

4 Department of Applied Biology-Nutrition, Institute of Bioengineering, University Miguel Hernández, 03202 Elche, Spain; eroche@umh.es

5 CIBER Physiopathology of Obesity and Nutrition (CIBEROBN), Instituto de Salud Carlos III (ISCIII), 28029 Madrid, Spain

6 Department of Biochemistry, Molecular Biology and Physiology, Faculty of Health Sciences, GIR of Physical Exercise and Aging, Campus Universitario "Los Pajaritos", Valladolid University, 42004 Soria, Spain

* Correspondence: a.cordova@uva.es

Citation: Caballero-García, A.; Noriega, D.C.; Bello, H.J.; Roche, E.; Córdova-Martínez, A. The

Immunomodulatory Function of Vitamin D, with Particular Reference to SARS-CoV-2. Medicina 2021, 57, 1321. https://doi.org/10.3390/ medicina57121321

Academic Editors: Nicola Luigi Bragazzi and Shoenfeld Yehuda

Received: 27 October 2021

Accepted: 30 November 2021

Published: 2 December 2021

Publisher's Note: MDPI stays neutral with regard to jurisdictional claims in published maps and institutional affiliations.

Copyright: (c) 2021 by the authors. Licensee MDPI, Basel, Switzerland. This article is an open access article distributed under the terms and conditions of the Creative Commons Attribution (CC BY) license (https:// creativecommons.org/licenses/by/ $4.0 /)$.

\begin{abstract}
Vaccines are the only way to reduce the morbidity associated to SARS-CoV-2 infection. The appearance of new mutations urges us to increase the effectiveness of vaccines as a complementary alternative. In this context, the use of adjuvant strategies has improved the effectiveness of different vaccines against virus infections such as dengue, influenza, and common cold. Recent reports on patients infected by COVID-19 reveal that low levels of circulating vitamin D correlate with a severe respiratory insufficiency. The immunomodulatory activity of this micronutrient attenuates the synthesis of pro-inflammatory cytokines and at the same time, increases antibody production. Therefore, the present review proposes the use of vitamin D as adjuvant micronutrient to increase the efficacy of vaccines against SARS-CoV-2 infection.
\end{abstract}

Keywords: immunomodulation; vaccination; vitamin D

\section{Introduction}

Vaccines are the most effective strategy to limit the extent of infection caused by SARSCoV-2 virus, known as COVID-19. Vaccines represent a powerful strategy to reduce the morbidity associated with the disease. Nevertheless, alternative pharmacological protocols based on dexamethasone administration [1] and immunotherapy based on the used of interleukin-6 (IL-6) receptor agonists [2] should be taken into account as well.

Regarding vaccination, some studies have reported that vaccines encoding the SARSCoV S protein elicited potent cellular and humoral immune responses in rodent models and in clinical trials $[3,4]$. In this context, the spike $(S)$ protein of coronaviruses is crucial in SARS-CoV-2 infection. For this reason, $S$ protein of SARS-CoV-2 has been identified as the most suitable target for vaccine development to trigger virus-specific T-cell responses as well as humoral immune responses [5]. The use of the $S$ protein as an antigen provides protective antibodies that neutralise the virus and prevent infection, leading to an optimal cellular response [6,7]. The S protein contains two subunits, S1 and S2, which mediate receptor binding and membrane fusion, respectively. The S1 subunit contains a sequence called the receptor-binding domain (RBD) that is able to bind to angiotensin-converting 
enzyme-2 (ACE-2) receptor [8]. This particular domain used as an antigen is able to induce neutralizing antibodies and T-cell immune responses $[9,10]$. On the other hand, the administration of a single dose of adenovirus type 5-vectored COVID-19 vaccine in healthy individuals is safe and well tolerated [11]. This vaccine variant produces specific antiviral Tcell and humoral immune responses after 2 weeks of administration. In addition, a marked increase in the production of interferon- $\gamma$ (IFN- $\gamma)$, tumour necrosis factor- $\alpha$ (TNF- $\alpha$ ) and interleukin-2 (IL-2) by CD4+ and CD8+ T cells post-vaccination has been observed [11].

In any case, the mechanism of COVID-19 vaccines could be summarized in three aspects: (a) mRNA vaccines that instruct the cells of the recipient to synthesize a harmless protein exclusive of COVID-19; (b) vaccines containing subunits or harmless portions of SARS-CoV-2 proteins; and (c) vector vaccines containing a modified version of a virus different of COVID-19. So far, the data suggest that all these vaccines offer protection against the disease, decreasing morbidity and mortality [12,13].

SARS-CoV-2 infection is a heterogeneous process, depending on age, sex, ethnicity, and comorbidities, among others. The dynamics of transmission of the virus and its contagion capacity remains to be established due to the appearance of new mutations. Therefore, avoiding transmission between patients is not the only strategy. To increase the effectiveness of vaccines should also be taken into account as a complementary safe alternative [14].

The evaluation of the efficiency and effectiveness of COVID-19 vaccines is complex, due to the lack of knowledge about the pathophysiology of the disease, and the diversity of vaccine formulations and strategies. The efficiency of a vaccine can be assessed based on the reduction of the infection percentage among vaccinated people compared to the frequency of infection among those who were not vaccinated, assuming that the vaccine is the cause of infection reduction. However, effectiveness represents the general health benefits provided by a vaccination program in the population. However, good efficiency does not always mean good effectiveness [15].

The use of adjuvant strategies can increase the effectiveness of vaccines against SARS$\mathrm{CoV}-2$, as observed in other vaccination protocols against other infectious diseases. In this context, one of the candidate nutrients is vitamin $\mathrm{D}$, which has been shown to have a protecting effect against some viral infections, including dengue, influenza, and common cold $[16,17]$. The possibility has also been raised that vitamin D may prevent and/or mitigate COVID-19 infection [18]. Alternative compounds with immunomodulatory properties, such as glucans, have also been proposed as adjuvants [19].

The evidence regarding vitamin D effect in infectious and inflammatory processes, allow us to propose that vitamin D supplementation could help in the defense process induced by vaccines. This could be achieved by improving the production of antibodies against SAR-CoV-2 and/or improving the immune response against viral antigens, modulating the response of cytokines and inflammatory messengers. Therefore, in this review we propose to analyze and give a molecular explanation to a candidate role of vitamin $\mathrm{D}$ as adjuvant in vaccination against SARS-CoV-2.

\section{Immune Response against SARS-CoV-2}

Coronaviruses activate a battery of innate immune cells, including neutrophils, monocytes/macrophages, natural killer cells (NKCs), T cells, mast cells, resident endothelial and epithelial cells. This wide activation induces a particular response known as "cytokine storm" [20-22].

The first response after SARS-CoV-2 infection is carried out by innate immune cells, mainly mast cells, commonly located in the nasal epithelium and lower respiratory tract [23]. The disease severity relies on the ability of innate immune cells to stop or mitigate the infection [24]. Therefore, protective immunity against SARS-CoV-2 lies in humoral and cellular responses (acquired or adaptive immunity) [23]. The production of neutralizing antibodies against infection or after vaccine administration gives rise to the proliferation of memory-specific T cells (CD4+ and CD8+) against SARS-CoV-2 [23]. 
Adaptive immune responses occur after the innate immune response, participating as well in the elimination of the virus immediately and in subsequent infections. In this context, $\mathrm{T}$ cells display the ability to destroy viruses, but need the participation of antigen-presenting cells (monocytes/macrophages, dendritic cells, neutrophil B cells, and mast cells). These cells can transfer antigens to memory $\mathrm{T}$ cells as well as to B lymphocytes [25]. However, many of the processes resulting from SARS-CoV-2 infection remain to be characterized in more detail, including the mechanisms operating in antigen presentation, the exact innate cellular and humoral responses, and the characterization in more detail of the above-mentioned cytokine storm [26].

Increased interleukin-6 levels in COVID-19 patients may induce differentiation of Th17 cells and stimulate cytokine storm, inflammation, and pulmonary dysfunction [27,28]. Th17 cells produce interleukin-17 members. However, this cytokine family is also secreted by other immune cells, including neutrophils, mast cells, NKCs, and innate lymphocytes $[29,30]$. Both antibody production and increased number of specific memory T cells are instrumental to long-term immune protection against SARS-CoV-2 and to the prevention of severe forms of COVID-19. However, this does not imply that the two processes are going in the same direction. For example, convalescent individuals seem to present a vigorous memory T-cell response several months after SARS-CoV-2 infection, even in the absence of circulating specific antibodies against SARS-CoV-2 [31].

The humoral response includes antibodies against $S$ protein and nucleocapsid protein (N). As mentioned before, $\mathrm{S} 1$ subunit of $\mathrm{S}$ protein contains the RBD that binds to ACE-2 receptor in human cells. Then, a rapid response appears with the production of virusspecific antibodies (IgG, IgA, and IgM) against different epitopes (antigenic determinants) of $S$ protein [32]. It seems that the severity of the disease depends on IgG and IgA levels. The lowest levels seem to appear in the mildest disease cases [33-35]. On the other hand, antibodies against RBD appear before antibodies against the $\mathrm{N}$ protein that is associated to viral genetic material during infection [36]. For this reason, anti-RBD antibodies are more specific and sensible for diagnosis than anti-N. Seroconversion of RBDs in patients is rapid and occurs frequently, displaying low cross-reactivity with SARS-CoV-2 [10,37].

In this line, mast cells are innate immune cells participating in adaptive immunity processes, such as certain stress disorders, inflammatory pathologies, and virus infections. Mast cells are widely distributed in the body systems, acting against the attack of infectious microorganisms (viruses and bacteria) and neutralizing toxins [38]. In this context, mast cells function differently, exerting a protective role but at the same time causing harmful effects in the organism [39,40].

On the other hand, it has been reported that patients with a low concentration of serum vitamin D have elevated D-dimer (protein fragment that appears during blood clotting) levels. In addition, these patients display high B cell counts, reduced CD8+ T cells, uncertain clinical prognosis, and affected chest computed tomography [41]. Altogether, vitamin $\mathrm{D}$ appears to play a central role in innate and adaptive immunity, although its effect on adaptive immune responses is not fully understood. However, at least part of these effects depends on the suppression of auxiliary type $1 \mathrm{~T}$ cells (Th1) and the stimulation of suppressive regulatory T cells [42].

\section{Inflammatory Response in COVID-19}

During SARS-CoV2 infection, damaged cells induce inflammation in different systemic locations. This process is largely mediated by pro-inflammatory cells, such as granulocytes and macrophages, causing the described symptoms of fever, cough, fibrosis, and a large increase in pro-inflammatory cytokine levels. Cytokines are secreted glycoproteins that regulate different functions of immune cells, including apoptosis, proliferation, differentiation, activation, and maturation of lymphocytes and accessory cells $[43,44]$. In acute COVID-19 cases, an exaggerated inflammatory response, known as "cytokine storm," has been described $[22,28,45]$. Finally, cytokines are also involved in the regulation of tissue distribution of leukocytes through the circulatory system [43,44]. 
Cytokines also modulate different functions in cells from various organs and body systems. Pleiotropy and redundancy in their functions are the main characteristics of these molecules. Cytokines include a wide family of extracellular messengers: interleukins, interferons, colony-stimulating factors, and many growth factors $[43,44]$. The main group of cytokines involved in leukocyte communication is the IL family. Other groups of cytokines modulate cell proliferation processes, such as colony-stimulating factors (e.g., granulocytemacrophage colony-stimulating factor, and granulocyte colony-stimulating factor/G-CSF). Others regulate tumor cytotoxicity, such as TNFs. Finally, other cytokines inhibit viral replication, such as IFNs $[43,44]$. Thus, modulation of the immune system is instrumental in the prevention and therapy for inflammatory diseases $[45,46]$.

The hyper-inflammatory response ("cytokine storm") induced by SARS-CoV-2 needs to be taken into account [47], but it does not seem to be the central pathological abnormality in COVID-19 [48]. In the early stages of infection, pro-inflammatory cytokines, and chemokines (CCL) are produced, including IL- $1 \beta$, IL-2, IL-6, IL-8, IFN- $\alpha$, IFN- $\beta$, TNF- $\alpha$, CCL2, CCL3, CCL5, and inducible protein-10 (IP-10) [49]. In the subsequent hyper-inflammatory phase, severe COVID-19 cases dramatically increase the levels of IL-2, IL-6, IL-7, IL-10, IP-10, CCL2 (also known as monocyte chemoattractant protein-1/MCP1), TNF- $\alpha$, macrophage inflammatory protein- $1 \alpha$ (MIP1 $\alpha)$, and G-CSF. In particular, IL-6 and TNF- $\alpha$ display a wide range of fluctuation, in many cases exceeding the physiological range [49]. However, a lower production of these cytokines has been reported in patients with moderate SARS-CoV2 infection or in the early inflammatory stage. Thus, overproduction of cytokines and chemokines result in lung damage and life-threatening respiratory complications. This "cytokine storm" downregulates likely innate and adaptive immune responses against SARS-CoV-2 infection [50,51].

Low expression of IFN $-\gamma$ related to a decrease of CD4+ and CD8+ T cells as well as NKCs, has been reported in cases of severe COVID-19 infection [52]. A high IL-6/IFN ratio seems to predict high severity in COVID-19 as well as lung damage as a result of "cytokine storm" [53]. Viral proteins, and in particular two non-structural polyproteins of SARS-CoV-2, inhibit the secretion and signaling of IFN- $\gamma$ via Janus kinase (JAK) [54-56]. JAK blockade results in the decreased expression of the signal transducer and activator of transcription-1 (STAT1), a key transcription factor in the immune response [54].

The response of the immune system is directly modulated by the activity of the hypothalamus-pituitary-adrenal (HPA) axis. This interaction is established mainly through glucocorticoid secretion $[43,44,57]$. Stress subsequent to SARS-CoV-2 infection results in the release of the corticotrophin-releasing hormone (CRH) that triggers the HPA system [58]. In this context, Kempuraj et al. [59] indicate that mast cells respond to CRH and other neuropeptides that can initiate and exacerbate neuro-inflammation processes. The stress generated can diminish immune responses to infections compromising at the same time the response to vaccines [60].

\section{Cytokine Response in Inflammation}

Cytokines are extracellular glycoproteins produced mostly by leukocytes. These molecules modulate different processes in immune cells $[43,44,57,61]$. Cytokines are transiently secreted during the immune response. They bind with high affinity to specific membrane receptors to exert their effects in the target cells $[43,44,57,61]$. In this context, cytokines work as extracellular messengers in intercellular (paracrine) or systemic (endocrine) communication. Cytokines can stop their own synthesis by using autocrine, paracrine, or endocrine mechanisms, as well as the synthesis of other cytokines and their receptors. Inhibitory mechanisms comprise corticosteroid and eicosanoid synthesis, secretion of soluble receptors, and blockade of active signal transduction pathways [62].

Pleiotropy in their function is one the main characteristics of cytokines. In this context, IL-1, IL- 6 and TNF- $\alpha$ participate in most inflammatory processes. For this reason, they are considered the main targets for therapeutic protocols [43,44,61-65]. Inflammation results from a cascade of molecular and cellular events that lead to fever and dilation 
of capillaries. These stressor-triggered responses are decisive for host response, activating defense mechanisms and recovery of tissue homeostasis. These processes require the elimination of altered molecules (i.e., oxidized proteins) and debris from damaged tissues [66,67]. However, the effects of cytokines on cells and target systems during an immune process are flexible, showing different levels of response, particularly for IL-1 $\beta$, IL-6, and TNF- $\alpha[43,44,57,61-65]$.

In addition, IFN- $\alpha$ and IFN- $\beta$ are involved in the immune response against the virus. In addition to its role in immunity, IFN- $\gamma$ can modulate the inflammatory response as well. IFN- $\gamma$ is produced by NKCs, working as a robust macrophage activator and inducing the nonspecific defense in host cells $[68,69]$. In this context, IFN- $\gamma$ functions as a proinflammatory cytokine and increases the synthesis of additional inflammatory cytokines such as TNF- $\alpha$. At the same time, IFN- $\gamma$ regulates the expression of TNF- $\alpha$ receptors [70] and nitric oxide synthase (NOS) [71].

\section{Vitamin D}

Vitamin D has two main inactive precursors: Vitamin D2 (ergocalciferol) and Vitamin D3 (cholecalciferol). Vitamin D2 is synthesized by certain plants that are consumed through the diet. Vitamin D3 is synthesized in the skin after sun exposure. To be active, both forms need a double hydroxylation: one in the liver to form $25-(\mathrm{OH}) \mathrm{D}$ by the microsomal hydroxylase CYP2R1 for ergocalciferol and mitochondrial CYP27A1 for cholecalciferol, and the second hydroxylation in kidneys by the mitochondrial hydroxylase CYP27B1, yielding active $1,25-(\mathrm{OH})_{2} \mathrm{D}$. Vitamin $\mathrm{D}$ is instrumental in the modulation of basic physiological processes, such as growth and development, bone formation and homeostasis, and nerve transmission. In addition, vitamin D modulates cell oxidative capacity, energy production, and immune function [72-74]. 1,25-(OH $)_{2} \mathrm{D}$ functions as a ligand for vitamin D nuclear receptor (VDR), modulating the subsequent transcriptional events [75].

As an immunomodulatory micronutrient $[18,19]$, vitamin D participates in the differentiation of monocytes to macrophages, increasing their chemotactic and phagocytic ability, preventing immunopathology and favoring efferocytosis [76]. In this context, it has been described that there is a connection between low vitamin $D$ levels and increased risk of acute respiratory viral infections (ARVI) [77-80], leading to acute lung injury and respiratory distress syndrome [81]. Regarding other immune cell types such as dendritic cells, vitamin D diminish maturation and thereby, antigen presentation. In addition, vitamin $\mathrm{D}$ favors the expression of cathelicidin (an antimicrobial peptide), favoring microbial elimination [82]. Furthermore, vitamin D promotes a shift in T lymphocytes towards a Th2 profile and a Treg phenotype. This change may be explained by a direct action of vitamin $\mathrm{D}$ or an indirect pathway through vitamin D modulation of antigen-presenting cells [82].

\subsection{Vitamin D against Infection}

A relevant process in the immune system is the synthesis of the active form of vitamin $\mathrm{D}\left(1,25-(\mathrm{OH})_{2} \mathrm{D}\right)$ by antigen-presenting cells, including dendritic cells and macrophages [83]. The biosynthetic process seems to be modulated first, by the availability of 25-(OH)D, then by the induction of CYP27B1 hydroxylase by invading pathogens, and third by the transcriptional stimulation of target genes by the complex $1,25(\mathrm{OH})_{2} \mathrm{D}-\mathrm{VDR}$ in the cells of the immune system.

In situations of vitamin D deficiency, the immune response would be affected, resulting in a drop of the innate immune function [84]. Therefore, vitamin D deficiency increases vulnerability to viral infections and the risk of subsequent periodic infections. For example, low serum vitamin D levels were associated with increased incidence of high-burden viral diseases, including influenza, hepatitis, AIDS (acquired immunodeficiency syndrome), and COVID-19 [85].

Therefore, the beneficial role of vitamin $\mathrm{D}$ against infection seems to be supported by three main mechanisms. As mentioned before, the first one refers to the improvement in the immune response [86]. The second refers to the barrier effect exerted through the 
stimulation of genes that encode proteins related to cell integrity and intercellular junctions such as occludin (tight junctions), connexin 43 (gap junctions), and cadherin E (adherent junctions). In this regard, many viruses alter the integrity of these barriers, increasing the degree of infectivity [87]. Therefore, the capacity of vitamin D in maintaining the entire cell barrier offers a complementary protection against infection. The third mechanism refers to the inhibition of the renin gene expression that affects the renin-angiotensin system (RAS), allowing to the activation of ACE-2 enzyme. ACE-2 is similar to ACE of RAS but with a different substrate specificity. The end product of ACE is angiotensin II, a potent vasoconstrictor peptide. Meanwhile, ACE-2 is a membrane protein expressed in all tissues, but with a particular high expression in lung epithelial cells. ACE-2 cleaves angiotensin II producing angiotensin 1-7, which is vasodilator and anti-inflammatory peptide due to its action on Mas receptor. The Mas pathway activated by angiotensin 1-7 binding supresses the activation of the extracellular signal regulated kinase/nuclear factro- $\mathrm{KB}$ (NF- $\mathrm{KB}$ ) that plays a central role in inflammation [88,89]. As mentioned before, ACE-2 is the target of SARS-CoV-2.

\subsection{Vitamin D and COVID-19}

SARS-CoV-2 infection is associated with a wide variety of symptoms due to the interindividual differences in immune responses. According to clinical reports, when the virus enters the body, it first goes through an incubation stage. During this phase, if the host immune system produces a specific immune response, the virus is eliminated, and the host escapes disease progression [90]. If the host immune system cannot eliminate the virus in this initial stage, the virus can attack tissues displaying expression of ACE-2 receptors, such as lungs and kidneys. The result is an activation of inflammatory processes mediated by the innate immune system (particularly macrophages and Th1 cells) with secretion of pro-inflammatory cytokines such as IL-1 $\beta$ and IL-18. This causes further organ damage and leads to the severe phase of the disease [90,91].

Since vitamin D plays a key role in immune system regulation, it can be assumed that vitamin D levels may correlate to the probability of SARS-CoV-2 infection [90,92]. In this context, it has been suggested that binding of vitamin D to VDR may decrease progression of COVID-19 [78] by decreasing cytokine/chemokine storm, modulating reninangiotensin system, regulating neutrophil activation, maintaining the structure of the pulmonary epithelial barrier, stimulating repair processes in the epithelium, and reducing an increased risk of blood clotting [81,93-95] (Figure 1).

VDR is widely distributed in many tissues and works cooperating with other transcription factors. It also regulates expression of genes containing promoters with specific DNA sequences, called vitamin D response elements (VDRE) $[75,96]$. Due to the direct transcriptional activity, vitamin D-VDR complex modulates key physiological processes related to bone mineralization, detoxification actions, cell cycle events (including proliferation, differentiation, migration, and death), immune responses, as well as cellular metabolic processes [75,97].

Quesada et al. [98] suggested that administration of elevated doses of 25-(OH)D significantly reduced the stage of COVID-19 patients in emergency services. Low levels of circulating 25-(OH)D have been linked to an increased predisposition to SARS-CoV-2 infection [99] and severe progression of COVID-19 [100].

Finally, lymphocytes play an instrumental role in maintaining immune and inflammatory homeostasis, a key aspect to protect the body against viral infections [101]. In this context, the main part of the studies analyzed in the meta-analysis by Yang et al. [102] noticed that SARS-CoV-2 infection decreases the number of lymphocytes in the most severe cases. However, this reduction is not evident in mild COVID-19 cases [103]. A possible relation between circulating levels of vitamin $\mathrm{D}$ and lymphocyte numbers remains to be investigated. 


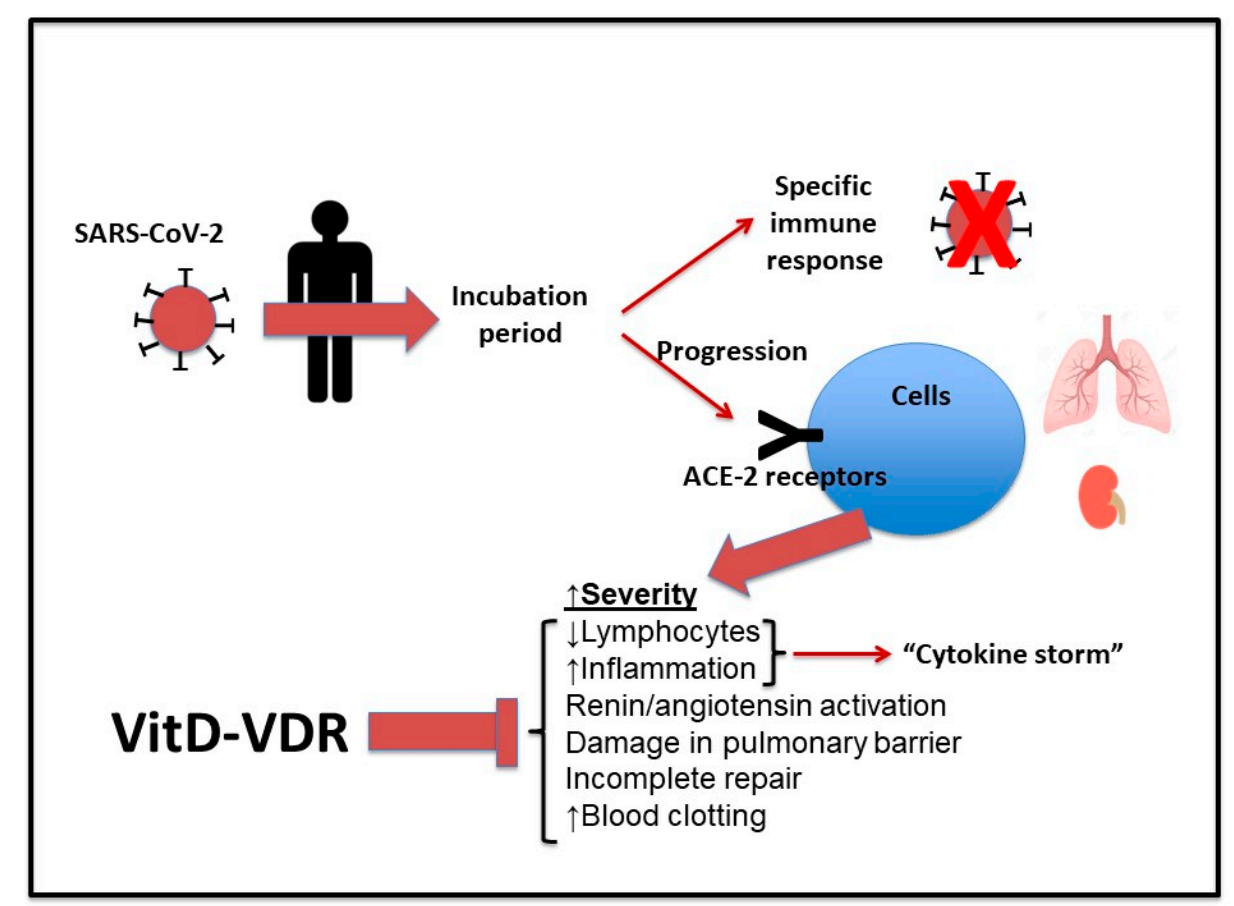

Figure 1. Scheme of the proposed role of vitamin D during SARS-CoV-2 infection. An incubation phase occurs when the virus enters the body. If the host produces a specific immune response, the virus is eliminated. If the host immune system cannot eliminate the virus, this can infect tissues with ACE-2 receptors (lungs and kidneys). The result is an increase in the severity of the disease. Vitamin D-VDR complex may attenuate the symptoms decreasing progression of COVID-19. ( $\uparrow$ ) Indicates activated process/increased number $(\downarrow)$ Decreases.

\subsection{Vitamin $D$ and the Inflammatory Response}

Sport performance at high intensities is a well described inflammatory process. Many studies indicate that vitamin D deficiency results in deficient recovery, subsequently affecting sport performance [104]. On the other hand, elevated circulating levels of vitamin D are related to low injury rates, indirectly improving performance [105]. Vitamin D seems to decrease inflammation by inhibiting the production of pro-inflammatory cytokines. These include IL-6, which promotes the conversion of monocytes into macrophages, increasing at the same time the synthesis of further pro-inflammatory cytokines. Vitamin D action seems to be similar to the anti-inflammatory activity of the immune-modulator AM3. This drug reduces the production of pro-inflammatory cytokines, such as IFN- $\alpha$, IL-2 and TNF$\alpha$ [106-109]. Therefore, these sports studies have provided key information regarding the anti-inflammatory role of vitamin $\mathrm{D}$ in post-exercise recovery.

In a health context, suboptimal levels of vitamin D are linked to chronic diseases and damage in skeletal muscle. The muscular effects of vitamin $\mathrm{D}$ require binding to the intracellular VDR $[107,110]$. The VDR-vitamin D complex regulates the expression of hundreds of genes that code for proteins that accomplish key cellular functions. In this context, the VDR-vitamin D complex stimulates eNOS expression, regulating at long term the synthesis of NO [107,110-113]. Regulated production of NO can promote angiogenesis of endothelial cells $[114,115]$. In addition, it has been shown that the absence of the VDR gene decreases the bioavailability of L-arginine (the precursor of NO). This results in an increased expression of arginase-2, an enzyme that converts L-arginine in ornithine and urea [112].

On the other hand, optimal circulating levels of vitamin $\mathrm{D}$ are instrumental in maintaining an efficient anti-inflammatory response $[116,117]$. Therefore, supplementation with $1,25(\mathrm{OH})_{2} \mathrm{D}$ to restore adequate circulating levels, suppresses pro-inflammatory cytokine expression [118], allowing the VDR-vitamin D complex to stimulate the recovery of skeletal 
muscle function [119-124]. The mechanisms proposed to explain the action of vitamin D in the restoration of muscle strength are: (a) modulating gene expression by direct binding of $1,25(\mathrm{OH})_{2} \mathrm{D}$ to VDR in muscle cells [125-127], and (b) promoting the transport of calcium into the sarcoplasmic reticulum necessary for muscle contraction (only tested in animal models) [125].

In this context, low levels of vitamin D in circulation are linked to impaired muscle function, decreased muscle strength and disorders in muscle metabolism [128]. The evidence suggests that supplementation with correct levels of vitamin D restores performance and avoids muscle injuries, improving muscle strength [129]. At a subcellular level, vitamin D supplements improve mitochondrial function, evidenced by correct morphology, stimulated mitochondrial protein synthesis, and inhibition of free radical production [130]. Therefore, vitamin D deficiency favors oxidative stress resulting from mitochondrial dysfunction in skeletal muscle [131].

Therefore, vitamin D plays a key role in the control of inflammation. However, the modulation of the anti-inflammatory response remains to be investigated in the control and destruction of respiratory pathogens, including SARS-CoV-2 [132,133].

\section{Why Vitamin D Could Act as Adjuvant in the Vaccination Protocol in COVID-19}

Currently, vaccines are a better tool in the prevention of infectious diseases, such as COVID-19. Vaccines against SARS-CoV-2 present different types [12,13]: administration with a single dose, vaccination with two doses and vaccination with a third dose. Therefore, several vaccination protocols are under research. However, we think that it would be important to consider the possibility of using adjuvants to improve vaccine performance, independently of the dose number.

The role of cytokines should be considered instrumental in the vaccination process. As indicated before, cytokines regulate the distribution of circulating leukocytes and exert modulatory effects on target cells of various organs and body systems [134-136]. Certain cytokines produce cytotoxicity and inhibition of viral replication, such as TNFs and IFNs, respectively [134-137]. Therefore, cytokines play a key function in the immune response against viral infection [138]. In this context, vitamin D modulates the expression of proinflammatory cytokines. Downregulation of the adaptive immune response in patients with severe COVID-19 presents a marked decrease in CD4+, CD8+ and regulatory T cells, accelerating the production of pro-inflammatory cytokines [139,140].

In mice, vitamin $\mathrm{D}$ favors the migration of skin dendritic cells to Peyer plaques after antigen-induced maturation [141]. In this context, dendritic cells work as antigenpresenting cells for activation of immunity in mucosal tissues [141]. The immune-stimulant effects on the response to antigens in circulation and mucosal tissues with the administration of 1,25- $(\mathrm{OH})_{2} \mathrm{D}$ have been described in pigs [142] and cattle [143]. However, recent reports on the use of $1,25-(\mathrm{OH})_{2} \mathrm{D}$ as an immune-modulator with a flu vaccine did not show an increase in antigen-specific immune response [144,145].

The immune-regulatory effects of vitamin $\mathrm{D}$ are primarily due to the activation of anti-inflammatory signaling pathways. In this context, vitamin D has been used as a beneficial adjuvant in vaccination against tuberculosis [146]. These authors indicate that vitamin $\mathrm{D}$ may exert a function in the immunity induced by vaccination against BCG (Bacillus Calmette-Guérin) contributing likely to the non-specific effects described after vaccination [146].

In addition, $1,25-(\mathrm{OH})_{2} \mathrm{D}$ has been administered to mice vaccinated with different vaccines, such as inactivated polio vaccine (IPV) [147], Hemophilus influenzae type b oligosaccharide conjugated with diphtheria toxoid vaccine [142], and hepatitis B surface antigen (HBsAg) vaccine [145]. In all these cases, the $1,25-(\mathrm{OH})_{2} \mathrm{D}$ administration stimulated the production of antigen-specific immunity in mucosal tissues (IgA and $\operatorname{IgG}$ antibodies), resulting in a greater systemic immune response [82,142,147,148]. 


\section{Conclusions}

Although the function of vitamin D in different body systems offers many possible interactions against the mechanisms by which the SARS-CoV-2 virus infects humans, the available data are still not conclusive. However, in view of the evidences presented in this review, we think that vitamin D may be a good adjuvant element in vaccination (Figure 2). Possible action mechanisms include attenuation of pro-inflammatory cytokine production and at the same time increasing the production of antibodies. Recent reports on circulating vitamin D levels in COVID-19 patients reveal a correlation between vitamin D insufficiency and the severity of respiratory disease caused by SARS-CoV-2. Higher COVID-19-related mortality has also been observed in countries with low average vitamin D circulating levels $[149,150]$.

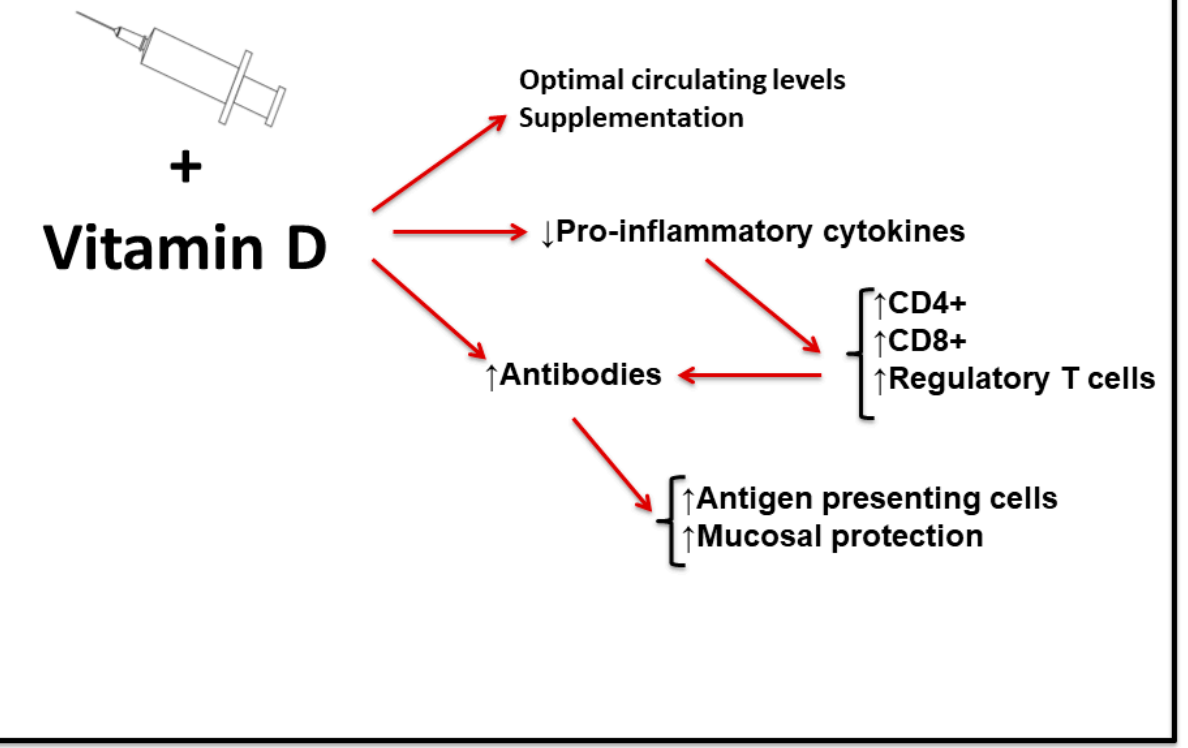

Figure 2. Scheme of the proposed adjuvant effect of vitamin D for COVID-19 vaccination. Optimal circulating levels or supplementation with vitamin D may work as an adjuvant for COVID vaccination. Proposed mechanisms are attenuation of pro-inflammatory cytokine production and increasing the production of antibodies. ( $\uparrow$ ) Indicates activated process/increased number and $(\downarrow)$ indicates decreased production.

Author Contributions: Conceptualization, A.C.-M. and A.C.-G.; methodology, H.J.B., D.C.N. and A.C.M.; validation, A.C.-G. and D.C.N.; writing-original draft preparation, A.C.-M.; writing-review and editing, E.R.; supervision, A.C.-M.; project administration, A.C.-M.; funding acquisition, A.C.-M. All authors have read and agreed to the published version of the manuscript.

Funding: This study was supported by Caja Rural de Soria (Soria, Spain).

Acknowledgments: Caja Rural de Soria (Soria, Spain).

Conflicts of Interest: The authors declare no conflict of interest.

\section{References}

1. RECOVERY Collaborative Group; Horby, P.; Lim, W.S.; Emberson, J.R.; Mafham, M.; Bell, J.L.; Linsell, L.; Staplin, N.; Brightling, C.; Ustianowski, A.; et al. Dexamethasone in hospitalized patients with Covid-19. N. Engl. J. Med. 2021, 384, 693-704. [CrossRef]

2. Ascierto, P.A.; Fox, B.A.; Urba, W.J.; Anderson, A.C.; Atkins, M.B.; Borden, E.C.; Brahmer, J.R.; Butterfield, L.H.; Cesano, A.; Chen, D.C.; et al. Insights from immuno-oncology: The Society for Immunotherapy of Cancer Statement on access to IL-6-targeting therapies for COVID-19. J. Immunother. Cancer 2020, 8, e000878. [CrossRef] 
3. Yang, Z.Y.; Kong, W.P.; Huang, Y.; Roberts, A.; Murphy, B.R.; Subbarao, K.; Nabel, G.J. A DNA vaccine induces SARS coronavirus neutralization and protective immunity in mice. Nature 2004, 428,561-564. [CrossRef]

4. Martin, J.E.; Louder, M.K.; Holman, L.A.; Gordon, I.J.; Enama, M.E.; Larkin, B.D.; Andrews, C.A.; Vogel, L.; Koup, R.A.; Roederer, M.; et al. A SARS DNA vaccine induces neutralizing antibody and cellular immune responses in healthy adults in a Phase I clinical trial. Vaccine 2008, 26, 6338-6343. [CrossRef]

5. Amanat, F.; Krammer, F. SARS-CoV-2 vaccines: Status report. Immunity 2020, 52, 583-589. [CrossRef]

6. Du, L.; He, Y.; Zhou, Y.; Liu, S.; Zheng, B.J.; Jiang, S. The spike protein of SARS-CoV-A target for vaccine and therapeutic development. Nat. Rev. Microbiol. 2009, 7, 226-236. [CrossRef]

7. Yang, J.; Wang, W.; Chen, Z.; Lu, S.; Yang, F.; Bi, Z.; Bao, L.; Mo, F.; Li, X.; Huang, Y.; et al. A vaccine targeting the RBD of the S protein of SARS-CoV-2 induces protective immunity. Nature 2020, 586, 572-577. [CrossRef]

8. Wan, Y.; Shang, J.; Graham, R.; Baric, R.S.; Li, F. Receptor recognition by the novel Coronavirus from Wuhan: An analysis based on decade-long structural studies of SARS Coronavirus. J. Virol. 2020, 94, e00127-20. [CrossRef]

9. He, Y.; Zhou, Y.; Siddiqui, P.; Jiang, S. Inactivated SARS-CoV vaccine elicits high titers of spike protein-specific antibodies that block receptor binding and virus entry. Biochem. Biophys. Res. Commun. 2004, 325, 445-452. [CrossRef]

10. Suthar, M.S.; Zimmerman, M.G.; Kauffman, R.C.; Mantus, G.; Linderman, S.L.; Hudson, W.H.; Vanderheiden, A.; Nyhoff, L.; Davis, C.W.; Adekunle, O.; et al. Rapid generation of neutralizing antibody responses in COVID-19 patients. Cell. Rep. Med. 2020, 1, 100040. [CrossRef]

11. Zhu, F.C.; Li, Y.H.; Guan, X.H.; Hou, L.H.; Wang, W.J.; Li, J.X.; Wu, S.P.; Wang, B.S.; Wang, Z.; Wang, L.; et al. Safety, tolerability, and immunogenicity of a recombinant adenovirus type- 5 vectored COVID-19 vaccine: A dose-escalation, open-label, non-randomised, first-in-human trial. Lancet 2020, 395, 1845-1854. [CrossRef]

12. Forni, G.; Mantovani, A.; Commission of Accademia Nazionale dei Lincei, Rome. Covid-19 vaccines: Where we stand and challenges ahead. Cell. Death Differ. 2021, 28, 626-639. [CrossRef]

13. Krammer, F. SARS-CoV-2 vaccines in development. Nature 2020, 586, 516-527. [CrossRef]

14. Pereira, N.L.; Ahmad, F.; Byku, M.; Cummins, N.W.; Morris, A.A.; Owens, A.; Tuteja, S.; Cresci, S. COVID-19: Understanding inter-individual variability and implications for precision medicine. Mayo. Clin. Proc. 2021, 96, 446-463. [CrossRef]

15. Bartlett, B.L.; Tyring, S.K. Safety and efficacy of vaccines. Dermatol. Ther. 2009, 22, 97-103. [CrossRef]

16. Lei, W.T.; Shih, P.C.; Liu, S.J.; Lin, C.-Y.; Yeh, T.-L. Effect of probiotics and prebiotics on immune response to influenza vaccination in adults: A systematic review and meta-analysis of randomized controlled trials. Nutrients 2017, 9, 1175. [CrossRef]

17. Grant, W.B.; Lahore, H.; McDonnell, S.L.; Baggerly, C.A.; French, C.B.; Aliano, J.L.; Bhattoa, H.P. Evidence that vitamin D supplementation could reduce risk of influenza and COVID-19 infections and deaths. Nutrients 2020, 12, 988. [CrossRef]

18. Mariani, J.; Tajer, C.; Antonietti, L.; Inserra, F.; Ferder, L.; Manucha, W. High-dose vitamin D versus placebo to prevent complications in COVID-19 patients: Study protocol of a multicentre, randomized, controlled clinical trial (CARED TRIAL). Trials 2021, 22, 111. [CrossRef]

19. Vetvicka, V.; Vannucci, L.; Sima, P.; Richter, J. Beta glucan: Supplement or drug? From laboratory to clinical trials. Molecules 2019, 24, 1251. [CrossRef]

20. Azkur, A.K.; Akdis, M.; Azkur, D.; Sokolowska, M.; van de Veen, W.; Bruggen, M.C.; O’Mahony, L.; Gao, Y.; Nadeau, K.; Akdis, C.A. Immune response to SARS-CoV-2 and mechanisms of immunopathological changes in COVID-19. Allergy 2020, 75, 1564-1581. [CrossRef]

21. Sun, X.; Wang, T.; Cai, D.; Hu, Z.; Chen, J.; Liao, H.; Zhi, L.; Wei, H.; Zhang, Z.; Qiu, Y.; et al. Cytokine storm intervention in the early stages of COVID-19 pneumonia. Cytokine Growth Factor Reviews 2020, 53, 38-42. [CrossRef]

22. Ye, Q.; Wang, B.; Mao, J. The pathogenesis and treatment of the "cytokine storm" in COVID-19. J. Infect. 2020, 80, 607-613. [CrossRef]

23. Kritas, S.K.; Ronconi, G.; Caraffa, A.; Gallenga, C.E.; Ross, R.; Conti, P. Mast cells contribute to coronavirus-induced inflammation: New anti-inflammatory strategy. J. Biol. Regul. Homeost. Agents 2020, 34, 9-14. [CrossRef]

24. Dastoli, S.; Bennardo, L.; Patruno, C.; Nisticò, S.P. Are erythema multiforme and urticaria related to a better outcome of COVID-19? Dermatol. Ther. 2020, 33, e13681. [CrossRef]

25. Netea, M.G.; Schlitzer, A.; Placek, K.; Joosten, L.A.B.; Schultze, J.L. Innate and adaptive immune memory: An evolutionary continuum in the host's response to pathogens. Cell. Host. Microbe 2019, 25, 13-26. [CrossRef]

26. Bennardo, L.; Nisticò, S.P.; Dastoli, S.; Provenzano, E.; Napolitano, M.; Silvestri, M.; Passante, M.; Patruno, C. Erythema multiforme and COVID-19: What do we know? Medicina 2021, 57, 828. [CrossRef]

27. Hotez, P.J.; Bottazzi, M.E.; Corry, D.B. The potential role of Th17 immune responses in coronavirus immunopathology and vaccine-induced immune enhancement. Microbes Infect. 2020, 22, 165-167. [CrossRef]

28. Wu, D.; Yang, X.O. TH17 responses in cytokine storm of COVID-19: An emerging target of JAK2 inhibitor Fedratinib. J. Microbiol. Immunol. Infect. 2020, 53, 368-370. [CrossRef]

29. Harrington, L.E.; Hatton, R.D.; Mangan, P.R.; Turner, H.; Murphy, T.L.; Murphy, K.M.; Weaver, C.T. Interleukin 17-producing CD4+ effector T cells develop via a lineage distinct from the T helper type 1 and 2 lineages. Nat. Immunol. 2005, 6, 1123-1132. [CrossRef]

30. Amatya, N.; Garg, A.V.; Gaffen, S.L. IL-17 signaling: The Yin and the Yang. Trends Immunol. 2017, 38, 310-322. [CrossRef]

31. Altmann, D.M. Adaptive immunity to SARS-CoV-2. Oxf. Open Immunol. 2020, 1, iqaa003. [CrossRef] [PubMed] 
32. Carrillo, J.; Izquierdo-Useros, N.; Ávila-Nieto, C.; Pradenas, E.; Clotet, B.; Blanco, J. Humoral immune responses and neutralizing antibodies against SARS-CoV-2; implications in pathogenesis and protective immunity. Biochem. Biophys. Res. Commun. 2021, 538, 187-191. [CrossRef]

33. Zhao, J.; Yuan, Q.; Wang, H.; Liu, W.; Liao, X.; Su, Y.; Wang, X.; Yuan, J.; Li, T.; Li, J.; et al. Antibody responses to SARS-CoV-2 in patients of novel coronavirus disease 2019. Clin. Infect. Dis. 2020, 71, 2027-2034. [CrossRef] [PubMed]

34. Long, Q.X.; Liu, B.Z.; Deng, H.J.; Wu, G.H.; Deng, K.; Chen, Y.K.; Liao, P.; Qiu, J.F.; Lin, Y.; Cai, X.F.; et al. Antibody responses to SARS-CoV-2 in patients with COVID-19. Nat. Med. 2020, 26, 845-848. [CrossRef]

35. Hu, W.C.; Howell, J.C.; Ozturk, T.; Benameur, K.; Bassit, L.C.; Ramonell, R.; Cashman, K.S.; Pirmohammed, S.; Roback, J.D.; Marconi, V.C.; et al. Antibody profiles according to mild or severe SARS-CoV-2 infection, Atlanta, Georgia, USA, 2020. Emerg. Infect. Dis. 2020, 26, 2974-2978. [CrossRef]

36. Premkumar, L.; Segovia-Chumbez, B.; Jadi, R.; Martínez, D.R.; Raut, R.; Markmann, A.; Cornaby, C.; Bartelt, L.; Weiss, S.; Park, Y.; et al. The receptor binding domain of the viral spike protein is an immunodominant and highly specific target of antibodies in SARS-CoV-2 patients. Sci. Immunol. 2020, 5, eabc8413. [CrossRef]

37. Chia, W.N.; Tan, C.W.; Foo, R.; Kang, A.E.; Peng, Y.; Sivalingam, V.; Tiu, C.; Ong, X.M.; Zhu, F.; Young, B.E.; et al. Serological differentiation between COVID-19 and SARS infections. Emerg. Microbes. Infect. 2020, 9, 1497-1505. [CrossRef]

38. Kempuraj, D.; Thangavel, R.; Natteru, P.A.; Selvakumar, G.P.; Saeed, D.; Zahoor, H.; Zaheer, S.; Iyer, S.S.; Zaheer, A. Neuroinflammation induces neurodegeneration. J. Neurol. Neurosurg. Spine 2016, 1, 1003.

39. Mukai, K.; Tsai, M.; Saito, H.; Galli, S.J. Mast cells as sources of cytokines, chemokines, and growth factors. Immunol. Rev. 2018, 282, 121-150. [CrossRef] [PubMed]

40. Varricchi, G.; Rossi, F.W.; Galdiero, M.R.; Granata, F.; Criscuolo, G.; Spadaro, G.; de Paulis, A.; Marone, G. Physiological roles of mast cells: Collegium Internationale Allergologicum update 2019. Int. Arch. Allergy Immunol. 2019, 179, 247-261. [CrossRef] [PubMed]

41. Ricci, A.; Pagliuca, A.; D'Ascanio, M.; Innammorato, M.; De Vitis, C.; Mancini, R.; Giovagnoli, S.; Facchiano, F.; Sposato, B.; Anibaldi, P.; et al. Circulating vitamin D levels status and clinical prognostic indices in COVID-19 patients. Respir. Res. 2021, 22, 76. [CrossRef]

42. Shakoor, H.; Feehan, J.; Al Dhaheri, A.S.; Ali, H.I.; Platat, C.; Ismail, L.C.; Apostolopoulos, V.; Stojanovska, L. Immune-boosting role of vitamins D, C, E, zinc, selenium and omega-3 fatty acids: Could they help against COVID-19? Maturitas 2021, 143, 1-9. [CrossRef] [PubMed]

43. Hayat, M. Immunology; Academic Press: New York, NY, USA, 2017.

44. Córdova, A.; Alvarez de Mon, M. Inmunidad en el Deporte; Gymnos: Madrid, Spain, 2001.

45. Mehta, P.; McAuley, D.F.; Brown, M.; Sánchez, E.; Tattersall, R.S.; Manson, J.J. COVID-19: Consider cytokine storm syndromes and immunosuppression. Lancet 2020, 395, 1033-1034. [CrossRef]

46. Dinarello, C.A. Anti-cytokine therapeutics and infections. Vaccine 2003, 21, S24-S34. [CrossRef]

47. Merad, M.; Martin, J.C. Pathological inflammation in patients with COVID-19: A key role for monocytes and macrophages. Nat. Rev. Immunol. 2020, 20, 355-362. [CrossRef]

48. Osuchowski, M.F.; Winkler, M.S.; Skirecki, T.; Cajander, S.; Shankar-Hari, M.; Lachmann, G.; Monneret, G.; Venet, F.; Bauer, M.; Brunkhorst, F.M.; et al. The COVID-19 puzzle: Deciphering pathophysiology and phenotypes of a new disease entity. Lancet Respir. Med. 2021, 9, 622-642. [CrossRef]

49. Hu, B.; Huang, S.; Yin, L. The cytokine storm and COVID-19. J. Med. Virol. 2021, 93, 250-256. [CrossRef]

50. Pontelli, M.C.; Castro, I.A.; Martins, R.B.; Veras, F.P.; La Serra, L.; Nascimento, D.C.; Cardoso, R.S.; Rosales, R.; Lima, T.M.; Souza, J.P.; et al. Infection of human lymphomononuclear cells by SARS-Cov-2. bioRxiv 2020. [CrossRef]

51. Zheng, F.; Zhou, Y.; Zhou, Z.; Ye, F.; Huang, B.; Huang, Y.; Ma, J.; Zuo, Q.; Tan, X.; Xie, J.; et al. SARS-CoV-2 clearance in COVID-19 patients with Novaferon treatment: A randomized, open-label, parallel-group trial. Int. J. Infect. Dis. 2020, 99, 84-91. [CrossRef] [PubMed]

52. Chen, G.; Wu, D.; Guo, W.; Cao, Y.; Huang, D.; Wang, H.; Wang, T.; Zhang, X.; Chen, H.; Yu, H.; et al. Clinical and immunologic features in severe and moderate forms of Coronavirus disease. J. Clin. Investig. 2020, 130, 137244. [CrossRef]

53. Lagunas-Rangel, F.A.; Chávez-Valencia, V. High IL-6/IFN- $\gamma$ ratio could be associated with severe disease in COVID-19 patients. J. Med. Virol. 2020, 92, 1789-1790. [CrossRef]

54. De Wit, E.; van Doremalen, N.; Falzarano, D.; Munster, V.J. SARS and MERS: Recent insights into emerging coronaviruses. Nat. Rev. Microbiol. 2016, 14, 523. [CrossRef] [PubMed]

55. Bianchi, M.; Benvenuto, D.; Giovanetti, M.; Angeletti, S.; Ciccozzi, M.; Pascarella, S. Sars-CoV-2 envelope and membrane proteins: Structural differences linked to virus characteristics? BioMed Res. Int. 2020, 2020, 4389089. [CrossRef] [PubMed]

56. Astuti, I. Severe acute respiratory syndrome coronavirus 2 (SARS-Cov-2): An overview of viral structure and host response. Diabetes Metab. Syndr. 2020, 14, 407-412. [CrossRef]

57. Gleeson, M.; Bishop, N.; Walsh, N. Exercise Immunology; Routledge (Taylor-Francis Group): London, UK, 2013.

58. Steenblock, C.; Todorov, V.; Kanczkowski, W.; Eisenhofer, G.; Schedl, A.; Wong, M.L.; Licinio, J.; Bauer, M.; Young, A.H.; Gainetdinov, R.R.; et al. Severe acute respiratory syndrome coronavirus 2 (SARS-CoV-2) and the neuroendocrine stress axis. Mol. Psychiatry 2020, 7, 1-7. [CrossRef] 
59. Kempuraj, D.; Mentor, S.; Thangavel, R.; Ahmed, M.E.; Selvakumar, G.P.; Raikwar, S.P.; Dubova, I.; Zaheer, S.; Iyer, S.S.; Zaheer, A. Mast cells in stress, pain, blood-brain barrier, neuroinflammation and Alzheimer's disease. Front. Cell. Neurosci. 2019, 13, 54. [CrossRef] [PubMed]

60. Minihan, E.; Gavin, B.; Kelly, B.D.; McNicholas, F. Covid-19, mental health and psychological first aid. Ir. J. Psychol. Med. 2020, 14, 1-12. [CrossRef]

61. Regueiro, J.; López, C.; González, S.; Martínez, E. Inmunología. Biologíay Patología del Sistema Inmunitario; Editorial Medica Panamericana: Madrid, Spain, 2010.

62. Peake, J.M.; Della Gatta, P.; Suzuki, K.; Nieman, D.C. Cytokine expression and secretion by skeletal muscle cells: Regu-latory mechanisms and exercise effects. Exerc. Immunol. Rev. 2015, 21, 8-25.

63. Feghali, C.A.; Wright, T.M. Cytokines in acute and chronic inflammation. Front. Biosci. 1997, 2, 12-26. [CrossRef]

64. Dinarello, C.A. Proinflammatory cytokines. Chest 2000, 118, 503-508. [CrossRef]

65. Cerqueira, É.; Marinho, D.A.; Neiva, H.P.; Lourenço, O. Inflammatory effects of high and moderate intensity exercise-A systematic review. Front. Physiol. 2020, 10, 1550. [CrossRef]

66. Allen, J.; Sun, Y.; Woods, J.A. Exercise and the regulation of inflammatory responses. Prog. Mol. Biol. Transl. Sci. 2015, 135, 337-354. [CrossRef]

67. Moldoveanu, A.I.; Shephard, R.J.; Shek, P.N. The cytokine response to physical activity and training. Sports Med. 2001, 31, 115-144. [CrossRef] [PubMed]

68. Billiau, A. Interferon gamma: Biology and role in pathogenesis. Adv. Immunol. 1996, 62, 61-130. [CrossRef]

69. Viti, A.; Muscettola, M.; Paulesu, L.; Bocci, V.; Almi, A. Effect of exercise on plasma interferon levels. J. Appl. Physiol. 1985, 59, 426-428. [CrossRef]

70. Ruggiero, V.; Tavernier, J.; Fiers, W.; Baglioni, C. Induction of synthesis of tumor necrosis factor alpha by interferon gamma. J. Immunol. 1986, 136, 2445-2450.

71. Lowenstein, C.J.; Snyder, S.H. Nitric oxide, a novel biologic messenger. Cell 1992, 70, 705-707. [CrossRef]

72. Córdova, A. Fisiología Dinámica; Elsevier: Barcelona, Spain, 2003.

73. Baeke, F.; Takiishi, T.; Korf, H.; Gysemans, C.; Mathieu, C. Vitamin D: Modulator of the immune system. Curr. Opin. Pharmacol. 2010, 10, 482-496. [CrossRef] [PubMed]

74. Hewison, M. Vitamin D and innate and adaptive immunity. Vitam Horm 2011, 86, 23-62. [CrossRef]

75. Haussler, M.R.; Whitfield, G.K.; Kaneko, I.; Haussler, C.A.; Hsieh, D.; Hsieh, J.C.; Jurutka, P.W. Molecular mechanisms of vitamin D action. Calcif. Tissue Int. 2013, 92, 77-98. [CrossRef] [PubMed]

76. Xu, H.; Soruri, A.; Gieseler, R.K.; Peters, J.H. 1,25-Dihydroxyvitamin D3 exerts opposing effects to IL-4 on MHC class-II antigen expression, accessory activity, and phagocytosis of human monocytes. Scand. J. Immunol. 1993, 38, 535540. [CrossRef]

77. Zdrenghea, M.T.; Makrinioti, H.; Bagacean, C.; Bush, A.; Johnston, S.L.; Stanciu, L.A. Vitamin D modulation of innate immune responses to respiratory viral infections. Rev. Med. Virol. 2017, 2. [CrossRef]

78. Quesada-Gomez, J.M.; Entrenas-Castillo, M.; Bouillon, R. Vitamin D receptor stimulation to reduce acute respiratory distress syndrome (ARDS) in patients with coronavirus SARS-CoV-2 infections: Revised Ms SBMB 2020_166. J. Steroid. Biochem. Mol. Biol. 2020, 202, 105719. [CrossRef]

79. Ali, N. Role of vitamin D in preventing of COVID-19 infection, progression and severity. J. Infect. Public. Health 2020, 13, 1373-1380. [CrossRef] [PubMed]

80. Balla, M.; Merugu, G.P.; Konala, V.M.; Sangani, V.; Kondakindi, H.; Pokal, M.; Gayam, V.; Adapa, S.; Naramala, S.; Malayala, S.V. Back to basics: Review on vitamin D and respiratory viral infections including COVID-19. J. Community Hosp. Intern. Med. Perspect. 2020, 29, 529-536. [CrossRef] [PubMed]

81. Shi, Y.Y.; Liu, T.J.; Fu, J.H.; Xu, W.; Wu, L.; Hou, A.; Xue, X.D. Vitamin D/VDR signaling attenuates lipopolysaccharide-induced acutelung injury by maintaining the integrity of the pulmonary epithelial barrier. Mol. Med. Rep. 2016, 13, 1186-1194. [CrossRef]

82. Sadarangani, S.P.; Whitaker, J.A.; Poland, G.A. "Let there be light": The role of vitamin D in the immune response to vaccines. Expert. Rev. Vaccines 2015, 14, 1427-1440. [CrossRef] [PubMed]

83. Kallas, M.; Green, F.; Hewison, M.; White, C.; Kline, G. Rare causes of calcitriol-mediated hypercalcemia: A case report and literature review. J. Clin. Endocrinol. Metab. 2010, 95, 3111-3117. [CrossRef]

84. Hewison, M. Vitamin D and the intracrinology of innate immunity. Mol. Cell. Endocrinol. 2010, 321, 103-111. [CrossRef]

85. Siddiqui, M.; Manansala, J.S.; Abdulrahman, H.A.; Nasrallah, G.K.; Smatti, M.K.; Younes, N.; Althani, A.A.; Yassine, H.M. Immune modulatory effects of vitamin D on viral infections. Nutrients 2020, 12, 2879. [CrossRef]

86. Schwalfenberg, G.K. A review of the critical role of vitamin D in the functioning of the immune system and the clinical implications of vitamin D deficiency. Mol. Nutr. Food Res. 2011, 55, 96-108. [CrossRef]

87. Kast, J.I.; McFarlane, A.J.; Głobińska, A.; Sokolowska, M.; Wawrzyniak, P.; Sanak, M.; Schwarze, J.; Akdis, C.A.; Wanke, K. Respiratory syncytial virus infection influences tight junction integrity. Clin. Exp. Immunol. 2017, 190, 351-359. [CrossRef]

88. Diaz-Curiel, M.; Cabello, A.; Arboiro-Pinel, R.; Mansur, J.L.; Heili-Frades, S.; Mahillo-Fernandez, I.; Herrero-González, A.; Andrade-Poveda, M. The relationship between 25(OH) vitamin D levels and COVID-19 onset and disease course in Spanish patients. J. Steroid. Biochem. Mol. Biol. 2021, 212, 105928. [CrossRef]

89. Malek Mahdavi, A. A brief review of interplay between vitamin D and angiotensin-converting enzyme 2: Implications for a potential treatment for COVID-19. Rev. Med. Virol. 2020, 30, e2119. [CrossRef] [PubMed] 
90. Shi, Y.; Wang, Y.; Shao, C.; Huang, J.; Gan, J.; Huang, X.; Bucci, E.; Piacentini, M.; Ippolito, G.; Melino, G. COVID-19 infection: The perspectives on immune responses. Cell. Death Differ. 2020, 27, 1451-1454. [CrossRef]

91. Xu, Z.; Shi, L.; Wang, Y.; Zhang, J.; Huang, L.; Zhang, C.; Liu, S.; Zhao, P.; Liu, H.; Zhu, L.; et al. Pathological findings of COVID-19 associated with acute respiratory distress syndrome. Lancet Respir. Med. 2020, 8, 420-422. [CrossRef]

92. Kohlmeier, M. Avoidance of vitamin D deficiency to slow the COVID-19 pandemic. BMJ Nutr. Prev. Health 2020, 3, 67-73. [CrossRef]

93. Kong, J.; Zhu, X.; Shi, Y.; Liu, T.; Chen, Y.; Bhan, I.; Zhao, Q.; Thadhani, R.; Li, Y.C. VDR attenuates acute lung injury by blocking Ang-2-Tie-2 pathway and renin-angiotensin system. Mol. Endocrinol. 2013, 27, 2116-2125. [CrossRef] [PubMed]

94. Zheng, S.X.; Yang, J.X.; Hu, X.; Li, M.; Wang, Q.; Dancer, R.C.A.; Parekh, D.; Gao-Smith, F.; Thickett, D.R.; Jin, S. Vitamin D attenuates lung injury via stimulating epithelial repair, reducing epithelial cell apoptosis and inhibits TGF- $\beta$ induced epithelial to mesenchymal transition. Biochem. Pharmacol. 2020, 177, 113955. [CrossRef] [PubMed]

95. Martinez-Moreno, J.M.; Herencia, C.; De Oca, A.M.; Muñoz-Castañeda, J.R.; Rodríguez-Ortiz, M.E.; Diaz-Tocados, J.M.; PeralboSantaella, E.; Camargo, A.; Canalejo, A.; Rodriguez, M.; et al. Vitamin D modulates tissue factor and protease-activated receptor 2 expression in vascular smooth muscle cells. FASEB J. 2016, 30, 1367-1376. [CrossRef]

96. Rosen, C.J.; Adams, J.S.; Bikle, D.D.; Black, D.M.; Demay, M.B.; Manson, J.E.; Murad, M.H.; Kovacs, C.S. The nonskeletal effects of vitamin D: An Endocrine Society scientific statement. Endocr. Rev. 2012, 33, 456-492. [CrossRef]

97. Bikle, D.D. Vitamin D: Newly discovered actions require reconsideration of physiologic requirements. Trends Endocrinol. Metab. 2010, 21, 375-384. [CrossRef]

98. Quesada, J.A.; López-Pineda, A.; Gil-Guillén, V.F.; Arriero-Marín, J.M.; Gutiérrez, F.; Carratala-Munuera, C. Período de incubación de la COVID-19: Revisión sistemática y metaanálisis [Incubation period of COVID-19: A systematic review and meta-analysis]. Rev. Clin. Esp. 2021, 221, 109-117. [CrossRef] [PubMed]

99. D'Avolio, A.; Avataneo, V.; Manca, A.; Cusato, J.; De Nicolo, A.; Lucchini, R.; Keller, F.; Cantù, M. 25-hydroxyvitamin D concentrations are lower in patients with positive PCR for SARS-CoV-2. Nutrients 2020, 12, 1359. [CrossRef] [PubMed]

100. Panagiotou, G.; Tee, S.A.; Ihsan, Y.; Athar, W.; Marchitelli, G.; Kelly, D.; Boot, C.S.; Stock, N.; Macfarlane, J.; Martineau, A.R.; et al. Low serum 25- hydroxyvitamin D (25[OH]D) levels in patients hospitalised with COVID-19 are associated with greater disease severity. Clin. Endocrinol. 2020, 93, 508-511. [CrossRef] [PubMed]

101. Wang, F.; Hou, H.; Luo, Y.; Tang, G.; Wu, S.; Huang, M.; Liu, W.; Zhu, Y.; Lin, Q.; Mao, L.; et al. The laboratory tests and host immunity of COVID-19 patients with different severity of illness. JCI Insight 2020, 5, e137799. [CrossRef]

102. Yang, A.P.; Li, H.M.; Tao, W.Q.; Yang, X.J.; Wang, M.; Yang, W.J.; Liu, J.P. Infection with SARS-CoV-2 causes abnormal laboratory results of multiple organs in patients. Aging 2020, 12, 10059-10069. [CrossRef]

103. Álvarez-Mon, M.; Ortega, M.A.; Gasullaet, O.; Fortuny-Profitós, J.; Mazaira-Font, F.A.; Saurina, P.; Monserrat, J.; Plana, M.N.; Troncoso, D.; Moreno, J.S.; et al. A predictive model and risk factors for case fatality of COVID-19. J. Pers. Med. 2021, 11, 36. [CrossRef] [PubMed]

104. Shuler, F.D.; Wingate, M.K.; Moore, G.H.; Giangarra, C. Sports health benefits of vitamin D. Sports Health 2012,4 , 496-501. [CrossRef]

105. De la Puente Yagüe, M.; Collado, L.; Ciudad-Cabañas, M.J.; Cuadrado-Cenzual, M.A. Role of vitamin D in athletes and their performance: Current concepts and new trends. Nutrients 2020, 12, 579. [CrossRef]

106. Córdova, A.; Monserrat, J.; Villa, G.; Reyes, E.; Soto, M.A. Effects of AM3 (Inmunoferon) on increased serum concentrations of interleukin-6 and tumour necrosis factor receptors I and II in cyclists. J. Sports Sci. 2006, 24, 565-573. [CrossRef]

107. Córdova, A.; Sureda, A.; Pons, A.; Alvarez-Mon, M. Modulation of TNF- $\alpha$, TNF- $\alpha$ receptors and IL- 6 after treatment with AM3 in professional cyclists. J. Sports Med. Phys. Fitness 2015, 55, 345-351. [PubMed]

108. Steinacker, J.M.; Lormes, W.; Reissnecker, S.; Liu, Y. New aspects of the hormone and cytokine response to training. Eur. J. Appl. Physiol. 2004, 91, 382-391. [CrossRef]

109. Hennigar, S.R.; McClung, J.P.; Pasiakos, S.M. Nutritional interventions and the IL-6 response to exercise. FASEB J. 2017, 31, 3719-3728. [CrossRef]

110. Fernández-Lázaro, D.; Mielgo-Ayuso, J.; Seco-Calvo, J.; Córdova-Martínez, A.; Caballero-García, A.; Fernandez-Lázaro, C.I. Modulation of exercise-induced muscle damage, inflammation, and oxidative markers by curcumin supplementation in a physically active population: A systematic review. Nutrients 2020, 12, 501. [CrossRef] [PubMed]

111. Carrera-Quintanar, L.; Funes, L.; Herranz-López, M.; Martínez-Peinado, P.; Pascual-García, S.; Sempere, J.M.; Boix-Castejón, M.; Córdova, A.; Pons, A.; Micol, V.; et al. Antioxidant supplementation modulates neutrophil inflammatory response to exercise-induced stress. Antioxidants 2020, 9, 1242. [CrossRef] [PubMed]

112. Sureda, A.; Ferrer, M.D.; Tauler, P.; Maestre, I.; Aguiló, A.; Córdova, A.; Tur, J.A.; Roche, E.; Pons, A. Intense physical ac-tivity enhances neutrophil antioxidant gene expression. Immunocytochemistry evidence for catalase secretion. Free Rad. Res. 2007, 41, 874-883. [CrossRef]

113. Wang, T.; Zhang, X.; Li, J.J. The role of NF-kappaB in the regulation of cell stress responses. Int. Immunopharmacol. 2002, 2, 1509-1520. [CrossRef]

114. Kim, D.H.; Meza, C.A.; Clarke, H.; Kim, J.S.; Hickner, R.C. Vitamin D and endothelial function. Nutrients 2020, 12, 575. [CrossRef]

115. Kanikarla-Marie, P.; Jain, S.K. 1,25(OH)2D3 inhibits oxidative stress and monocyte adhesion by mediating the upregula-tion of GCLC and GSH in endothelial cells treated with acetoacetate (ketosis). J. Steroid. Biochem. Mol. Biol. 2016, 159, 94-101. [CrossRef] 
116. Baumann, H.; Gauldie, J. The acute phase response. Immunol. Today 1994, 15, 74-80. [CrossRef]

117. Kammüler, M.E. Recombinant human interleukin-6: Safety issues of a pleiotropic growth factor. Toxicology 1995, 105, 91-107. [CrossRef]

118. Pedersen, B.K.; Hoffman-Goetz, L. Exercise and the immune system: Regulation, integration, and adaptation. Physiol. Rev. 2000, 80, 1055-1081. [CrossRef] [PubMed]

119. Campbell, P.M.F.; Allain, T.J. Muscle strength and vitamin D in older people. Gerontology 2006, 52, 335-338. [CrossRef]

120. Dalakas, M.C. Immunotherapy of myositis: Issues, concerns and future prospects. Nature. Rev. Rheumatol. 2010, 6, 129-137. [CrossRef]

121. Marantes, I.; Achenbach, S.J.; Atkinson, E.J.; Khosla, S.; Melton, L.J., 3rd; Amin, S. Is vitamin D a determinant of muscle mass and strength? J. Bone Miner. Res. 2011, 26, 2860-2871. [CrossRef] [PubMed]

122. Bischoff-Ferrari, H.A. Relevance of vitamin D in muscle health. Rev. Endocr. Metab. Disord. 2012, 13, 71-77. [CrossRef] [PubMed]

123. Girgis, C.M.; Clifton-Bligh, R.J.; Hamrick, M.W.; Holick, M.F.; Gunton, J.E. The roles of vitamin D in skeletal muscle: Form, function, and metabolism. Endocr. Rev. 2013, 34, 33-83. [CrossRef]

124. Hamilton, B. Vitamin D and athletic performance: The potential role of muscle. Asian J. Sports Med. 2011, 2, 211-219. [CrossRef] [PubMed]

125. Ceglia, L. Vitamin D and skeletal muscle tissue and function. Mol. Aspects Med. 2008, 29, 407-414. [CrossRef]

126. Foo, L.H.; Zhang, Q.; Zhu, K.; Ma, G.; Hu, X.; Greenfield, H.; Fraser, D.R. Low vitamin D status has an adverse influence on bone mass, bone turnover, and muscle strength in Chinese adolescent girls. J. Nutr. 2009, 139, 1002-1007. [CrossRef]

127. Wacker, M.; Holick, M.F. Vitamin D-Effects on skeletal and extraskeletal health and the need for supplementation. Nutrients 2013, 5, 111-148. [CrossRef]

128. Beaudart, C.; Buckinx, F.; Rabenda, V.; Gillain, S.; Cavalier, E.; Slomian, J.; Petermans, J.; Reginster, J.Y.; Bruyère, O. The effects of vitamin D on skeletal muscle strength, muscle mass, and muscle power: A systematic review and meta-analysis of randomized controlled trials. J. Clin. Endocrinol. Metab. 2014, 99, 4336-4345. [CrossRef]

129. Salminen, M.; Saaristo, P.; Salonoja, M.; Vaapio, S.; Vahlberg, T.; Lamberg-Allardt, C.; Aarnio, P.; Kivelä, S.L. Vitamin D status and physical function in older Finnish people: A one-year follow-up study. Arch. Gerontol. Geriatr. 2015, 61, 419-424. [CrossRef]

130. Ryan, Z.C.; Craig, T.A.; Folmes, C.D.; Wang, X.; Lanza, I.R.; Schaible, N.S.; Salisbury, J.L.; Nair, K.S.; Terzic, A.; Sieck, G.C.; et al. 1alpha,25-Dihydroxyvitamin D3 regulates mitochondrial oxygen consumption and dynamics in human skeletal muscle cells. J. Biol. Chem. 2016, 291, 1514-1528. [CrossRef]

131. Dzik, K.P.; Kaczor, J.J. Mechanisms of vitamin D on skeletal muscle function: Oxidative stress, energy metabolism and anabolic state. Eur. J. Appl. Physiol. 2019, 119, 825-839. [CrossRef] [PubMed]

132. Lange, C.M.; Bojunga, J.; Ramos-López, E.; von Wagner, M.; Hassler, A.; Vermehren, J.; Herrmann, E.; Badenhoop, K.; Zeuzem, S.; Sarrazin, C. Vitamin D deficiency and a CYP27B1-1260 promoter polymorphism are associated with chronic hepatitis C and poor response to interferon-alfa based therapy. J. Hepatol. 2011, 54, 887-893. [CrossRef] [PubMed]

133. Jolliffe, D.A.; Greiller, C.L.; Mein, C.A.; Hoti, M.; Bakhsoliani, E.; Telcian, A.G.; Simpson, A.; Barnes, N.C.; Curtin, J.A.; Custovic, A.; et al. Vitamin D receptor genotype influences risk of upper respiratory infection. Br. J. Nutr. 2018, 120, 891-900. [CrossRef]

134. Chousterman, B.G.; Swirski, F.K.; Weber, G.F. Cytokine storm and sepsis disease pathogenesis. Semin. Immunopathol. 2017, 39, 517-528. [CrossRef]

135. Germolec, D.R.; Frawley, R.P.; Evans, E. Markers of inflammation. Methods Mol. Biol. 2010, 598, 53-73. [CrossRef] [PubMed]

136. Zhang, J.; An, J. Cytokines, inflammation, and pain. Int. Anesthesiol. Clin. 2007, 45, 27-37. [CrossRef]

137. Wong, C.K.; Lam, C.W.; Wu, A.K.; Ip, W.K.; Lee, N.L.; Chan, I.H.; Lit, L.C.; Hui, D.S.; Chan, M.H.; Chung, S.S.; et al. Plasma inflammatory cytokines and chemokines in severe acute respiratory syndrome. Clin. Exp. Immunol. 2004, 136, 95-103. [CrossRef]

138. Channappanavar, R.; Perlman, S. Pathogenic human coronavirus infections: Causes and consequences of cytokine storm and immunopathology. Semin. Immunopathol. 2017, 39, 529-539. [CrossRef] [PubMed]

139. Hu, L.; Chen, S.; Fu, Y.; Gao, Z.; Long, H.; Ren, H.-W.; Zuo, Y.; Wang, J.; Li, H.; Xu, Q.B.; et al. Risk factors associated with clinical outcomes in 323 coronavirus disease 2019 (COVID-19) hospitalized patients in Wuhan, China. Clin. Infect. Dis. 2020, 71, 2089-2098. [CrossRef] [PubMed]

140. Qin, C.; Zhou, L.; Hu, Z.; Zhang, S.; Yang, S.; Tao, Y.; Xie, C.; Ma, K.; Shang, K.; Wang, W.; et al. Dysregulation of immune response in patients with COVID-19 in Wuhan, China. Clin. Infect. Dis. 2020, 71, 762-768. [CrossRef] [PubMed]

141. Enioutina, E.Y.; Visic, D.; Daynes, R.A. The induction of systemic and mucosal immune responses to antigen-adjuvant compositions administered into the skin: Alterations in the migratory properties of dendritic cells appears to be important for stimulating mucosal immunity. Vaccine 2000, 18, 2753-2767. [CrossRef]

142. Van der Stede, Y.; Cox, E.; Van den Broeck, W.; Goddeeris, B.M. Enhanced induction of the IgA response in pigs by calcitriol after intramuscular immunization. Vaccine 2001, 19, 1870-1878. [CrossRef]

143. Reinhardt, T.A.; Stabel, J.R.; Goff, J.P. 1,25-dihydroxyvitamin D3 enhances milk antibody titers to Escherichia coli J5 vaccine. J Dairy Sci. 1999, 82, 1904-1909. [CrossRef]

144. Kriesel, J.D.; Spruance, J. Calcitriol (1,25-dihydroxy-vitamin D3) coadministered with influenza vaccine does not enhance humoral immunity in human volunteers. Vaccine 1999, 17, 1883-1888. [CrossRef]

145. McCluskie, M.J.; Weeratna, R.D. Novel adjuvant systems. Curr. Drug Targets Infect. Disord. 2001, 1, 263-271. [CrossRef] 
146. Lalor, M.K.; Floyd, S.; Gorak-Stolinska, P.; Weir, R.E.; Blitz, R.; Branson, K.; Fine, P.E.; Dockrell, H.M. BCG vaccination: A role for vitamin D? PLOS ONE 2011, 6, e16709. [CrossRef] [PubMed]

147. Ivanov, A.P.; Dragunsky, E.M.; Chumakov, K.M. 1,25-dihydroxyvitamin D3 enhances systemic and mucosal immune responses to inactivated poliovirus vaccine in mice. J. Infect. Dis. 2006, 193, 598-600. [CrossRef] [PubMed]

148. Daynes, R.A.; Enioutina, E.Y.; Butler, S.; Mu, H.H.; McGee, Z.A.; Araneo, B.A. Induction of common mucosal immunity by hormonally immunomodulated peripheral immunization. Infect. Immun. 1996, 64, 1100-1109. [CrossRef] [PubMed]

149. Ilie, P.C.; Stefanescu, S.; Smith, L. The role of vitamin D in the prevention of coronavirus disease 2019 infection and mortality. Aging Clin. Exp. Res. 2020, 32, 1195-1198. [CrossRef]

150. Benskin, L.L. A basic review of the preliminary evidence that COVID-19 risk and severity is increased in vitamin D deficiency. Front. Public Health 2020, 8, 513. [CrossRef] [PubMed] 